CFaculty of Veterinary Medicine, Zagazig University, 44511, Egypt

DOI: $10.21608 / z v j z .2019 .28659$.

\title{
Genetic Parameters, Breeding Values and Genetic Trends for Some Productive and Reproductive Traits of Holstein Cows in Egypt
}

\author{
Tamer M. Abdel-Hamid*, Khairy M. El-Bayoumi, Mahmoud S. El-Tarabany and Wafaa R.I.A. \\ Sherief
}

Animal Wealth Development Department, Faculty of Veterinary Medicine, Zagazig University, 44511, Egypt

\begin{abstract}
This study aimed to estimate the genetic parameters (heritability and genetic correlation), breeding value and genetic trends for some productive and reproductive traits of Holstein Friesian cows in Egypt with animal model statistical method. A total of 3400 lactation records collected from 1060 cow's progeny of 99 sires and 691 dams through the period from 1998 to 2010 were used in this study. Results of genetic correlations showed great variability from very high positive to very low negative values. High heritability estimates were recorded for all studied traits with the exception of days in milk, calving interval and days open which revealed low estimates. The ranges of cows breeding values have been found to be higher than either sires or dams for all studied traits. Genetic trends were positive for 305 -day milk yield $(2.68 \mathrm{~kg})$, age at first calving $(0.020)$, fat yield $(0.031 \mathrm{~kg})$, fat $\%(0.001 \%)$ and protein $\%(0.002 \%)$, but were negative for protein yield $(-0.098 \mathrm{~kg})$ and days open $(-0.219)$. In conclusion, higher range of the cow breeding values than either sires or dams revealed a wider genetic variation and a good opportunity for selecting the superior cows. Positive genetic trends for 305-day milk yield, age at first calving, fat $\%$, fat yield and protein $\%$ indicated that there was a genetic improvement in these traits in desirable direction, but negative genetic trends for days open and protein yield indicating a decrease in mean breeding value for these traits over the study period.
\end{abstract}

Keywords: Holstein, Calving interval, Breeding value, Genetic trend, Animal model.

\section{Introduction}

Two decades ago, Holstein cattle has been entered to Egypt and reared in commercial farms characterized by intensive housing, feeding and high level of good veterinary management to relatively approach the animal welfare level to avoid stress conditions. Several researchers have investigated the effect of genetic and non-genetic factors on productive and reproductive traits of Friesian cows under Egyptian conditions [1-3]. The profitability of dairy cattle operations could be effectively improved by the genetic improvement of economically important traits, especially milk yield [4]. This mainly depends upon genetic differences that a population encountered which could be measured by heritability estimate of a trait in a certain environment [5].

The efficiency of selection procedures could be visualized by determination of genetic trend as well as it is useful tool in the quantification of the genetic changes of the traits under selection over time. In addition to this, any mistakes in the direction of selection could be corrected [6]. Also, interpretation of genetic trend estimates is of value in monitoring the efficacy of the genetic improvement programs and ensures that the selection procedures directed toward the economically important traits. The objectives of this study were to estimate some genetic parameters (heritabilities and genetic correlations), breeding values and genetic trends for some productive (days in milk, total milk yield, 305-days milk yield, fat percentage, protein percentage, fat yield and protein yield) and reproductive traits (services per conception, days open, age at first calving and calving interval).

\section{Material and Methods}

\section{Herd management}

A herd of Holstein-Friesian cattle that belongs to a private farm (AlexandriaCopenhagen dairy farm), $76 \mathrm{~km}$ AlexandriaCairo desert road was used for production and reproduction data collection from 1998 to 2010. About 3400 lactation records of 1060 dairy cows (99 sires and 691 dams). Shaded open yards with a cool spraying system during the high atmospheric temperature were 
constructed for animals housing. Cows were grouped according to milk production and fed total mixed ration (TMR) all over the year. The access for feed was based on the productive and physiological status [7]. Animals have a free access to water. When the heifers have reached a live body weight of 350 $\mathrm{kg}$ they were artificially inseminated for the first time and rectally palpated about 60 days post insemination. Heat was detected visually by heat detectors (30 minute a.m. and p.m.) near predicted estrus. About day 60 postpartum, the cows in estrous were artificially inseminated. Cows were machine milked three times daily at $06.00 \mathrm{~h}, 14.00 \mathrm{~h}$ and $22.00 \mathrm{~h}$ in herringbone parlor Alfa Lafal 40 point. Afikim and Dairy Comb 305 computer recording systems were used for data recording. Milk yield was recorded three times/days, then daily and weekly milk averages were calculated for each cow. Calves suckled colostrum of their dams for 3 days and then they were separated. A dry period of two months between two successive lactations has been established.

\section{Traits recorded}

Traits recoded could be divided into:

a) Productive traits which include the following traits:-

Total milk yield (TMY) which is the total amount of milk produced after yielding the colostrums until the end of lactation; 305-days milk yield (305-DMY) represents the amount of milk produced by the cow during the first 305 days of lactation; Days in milk (DIM) which is the number of days during lactation that a cow has been milked; Dry period (DP) or the non-lactation period; Fat yield which is the amount of fat per kilogram in the total milk yield; Fat percentage that is the percentage of fat in the total milk yield; Protein yield which is the amount of protein per kilogram in the total milk yield and Protein percentage which is the percentage of protein in the total milk yield.

\section{b) Reproductive traits which include the following traits:-}

Age at first calving (AFC); Service per conception $(\mathrm{S} / \mathrm{C})$ which is the number of services required for the cow to be conceived; Days open (DO) that is the period per days between calving and conception and calving interval (CI) represents the average time interval per days between successive calving.

\section{Statistical analysis}

Restricted maximum likelihood (REML) procedures of the MTDFREML program [8] was used to estimate heritability, genetic correlations and breeding values of studied traits using the following model:

$$
\mathrm{y}=\mathrm{Xb}+\mathrm{Zu}+\mathrm{e}
$$

Where: $y$ : a vector of observations, $b$ : $a$ vector of fixed effects with an incidence matrix $X, u$ : a vector of random animal effects with incidence matrix $Z$, and e: a vector of random residual effects with mean equals zero and variance $\sigma_{\mathrm{e}}^{2}$.

Genetic trends were estimated as the regression of mean estimated breeding values of cows on their birth or calving dates for cows born between 1998 and 2010 using the following equation:

$$
Y i=a+b X i
$$

Yi: estimated breeding value of trait, $b$ : genetic trend, $\mathrm{Xi}=$ Year of calving and $\mathrm{a}=$ Genetic gain. First, breeding values of any trait was estimation, and then averages of breeding values of animals for that trait of that year were calculated. Finally, Regression analysis was used to determine the significance of genetic trend using SPSS (16.0).

\section{Results and Discussion}

\section{Genetic parameters}

\section{Genetic correlation}

Results of genetic correlations for some milk production and reproduction traits in Friesian cows were represented in Table 1. High positive genetic correlations were detected between TMY and 305-DMY (0.9) which was consistent with those reported previously [5, 9] Furthermore, TMY showed high positive genetic correlations between fat and protein yields $(0.84$ and 0.89 , respectively). These results are in agreement with the results of other researchers $[10,11]$. High positive genetic correlation between milk and fat yields (0.96) was previously recorded [12]. In addition, genetic correlation between TMY and DIM was high and positive (0.59) 
that was similar to Mariz [3]. These results indicated that production traits in HolsteinFriesian cows were influenced by the same sets of genes and selection for improvement in one trait will automatically improve the other.

Low negative and desirable genetic correlations were recorded between TMY and fat and protein percentages $(-0.04$ and -0.10 , respectively) that are comparable with others $[13,14]$. A negative genetic correlation of 0.32 between milk yield and fat percentage in Moroccan Holstein-Friesian cows has been recorded [12]. The genetic correlation of TMY with DP was negative (-0.52) which was disagreed with Salem et al. [1]. However, these estimates were agreed with those reported previously $[3,15]$. A negative genetic correlation of milk yield with DP (-0.96) was reported by Ahmed et al. [9]. On the other hand, the genetic correlations between TMY and CI were positive and moderate (0.34), which are in agreement with those recorded by other authors [11, 16]. Ahmed et al. [9] reported a negative genetic correlation between milk yield and CI (-0.56).

Table 1: Genetic correlation (above the diagonal) and heritability (the diagonal) for milk production and reproductive traits in Holstein-Friesian cows

\begin{tabular}{|c|c|c|c|c|c|c|c|c|c|c|c|}
\hline & TMY & $\begin{array}{l}305- \\
\text { DMY }\end{array}$ & DIM & $\begin{array}{c}\text { Fat } \\
\%\end{array}$ & $\begin{array}{c}\text { Fat } \\
\text { yield }\end{array}$ & $\begin{array}{c}\text { Protein } \\
\%\end{array}$ & $\begin{array}{c}\text { Protein } \\
\text { yield }\end{array}$ & DP & $\mathrm{S} / \mathrm{C}$ & $\mathrm{CI}$ & DO \\
\hline TMY & $\begin{array}{c}\mathbf{0 . 3 3} \\
\pm \mathbf{0 . 0 2 0}\end{array}$ & 0.90 & 0.59 & -0.04 & 0.84 & -0.10 & 0.89 & -0.52 & -0.25 & -0.34 & 0.18 \\
\hline 305-DMY & & $\begin{array}{c}\mathbf{0 . 3 3} \\
\pm \mathbf{0 . 0 2 0}\end{array}$ & 0.64 & -0.36 & 0.58 & -0.38 & 0.64 & -0.61 & -0.39 & 0.35 & 0.13 \\
\hline DIM & & & $\begin{array}{c}0.11 \\
\pm 0.018\end{array}$ & -0.49 & 0.19 & -0.48 & 0.27 & -0.62 & -0.17 & 0.77 & 0.80 \\
\hline Fat $\%$ & & & & $\begin{array}{c}0.38 \\
\pm 0.019\end{array}$ & 0.49 & 0.97 & 0.44 & 0.64 & -0.67 & 0.52 & -0.23 \\
\hline Fat yield & & & & & $\begin{array}{c}\mathbf{0 . 3 7} \\
\pm \mathbf{0 . 0 2 0}\end{array}$ & -0.41 & 0.99 & 0.25 & 0.09 & 0.39 & -0.07 \\
\hline Protein $\%$ & & & & & & $\begin{array}{c}0.25 \\
\pm 0.019\end{array}$ & 0.37 & 0.63 & -0.69 & 0.22 & -0.18 \\
\hline $\begin{array}{l}\text { Protein } \\
\text { yield }\end{array}$ & & & & & & & $\begin{array}{c}\mathbf{0 . 3 2} \\
\pm \mathbf{0 . 0 2 0}\end{array}$ & -0.27 & 0.08 & 0.44 & 0.02 \\
\hline DP & & & & & & & & $\begin{array}{c}0.24 \\
\pm 0.026\end{array}$ & 0.65 & 0.15 & -0.02 \\
\hline $\mathrm{S} / \mathrm{C}$ & & & & & & & & & $\begin{array}{c}0.43 \\
\pm 0.010\end{array}$ & $\begin{array}{l}\text { overestim } \\
\text { ate }\end{array}$ & 0.37 \\
\hline CI & & & & & & & & & & $\begin{array}{c}0.03 \\
\pm \mathbf{0 . 0 1 8}\end{array}$ & $\begin{array}{l}\text { overestim } \\
\text { ate }\end{array}$ \\
\hline DO & & & & & & & & & & & $\begin{array}{c}0.06 \\
\pm 0.015 \\
\end{array}$ \\
\hline
\end{tabular}

TMY, total milk yield; 305-DMY, 305-days milk yield; DIM, days in milk; DP, dry period; S/C, service per conception; CI, calving interval; DO, days open.

Medium negative and desirable genetic correlation was detected for TMY with S/C ($0.25)$. On the other hand, medium positive and undesirable genetic correlations were observed between TMY and DO (0.18). Concurrent results were confirmed by Toghiani and Elshalmani [11, 17], but controversy with Ahmed et al. [9], who observed a negative genetic relationship of milk yield with DO (0.49). The genetic correlations between 305DMYand fat and protein percentage were negative (-0.36 and -0.38), which are harmonious with those recorded by Sahebhonar [18], but its association with fat and protein yields were high and positive $(0.58$ and 0.64 , respectively), which are in agreement with those reported previously [10, 19]. Indeed, genetic correlation between 305DMYand DIM was high and positive (0.64) which confirmed those reported by Mariz [3]. The genetic correlation of lactation length with 305-DMY was high and positive (0.96) [9]. On the contrary, the genetic correlation 
between 305-DMY and DIM was low (0.16) [20].

The genetic correlations among $\mathrm{CI}$ and $305-$ day milk yield, fat $\%$, fat yield, protein $\%$ and protein yield were moderately positive $(0.35$, $0.32,0.39,0.22$ and 0.44 , respectively). These results are consistent with those reported by Van-Raden et al. [21] and Makgahlela et al. [22]. By contrast, negative significant genetic correlation between CI and protein production percent $(-0.27)$ on standardized lactation was registered by Riecka and Candrak [16]. Dry period showed highly positive genetic correlations with fat and protein percentages (0.64 and 0.63$)$, but the genetic correlations between it and each of fat and protein yields were negative $(-0.25$ and -0.27$)$. The genetic correlation that detected between fat and protein yields was high and positive (0.99) which is in parallel with those reported by others [10,23], who detected positive genetic relationships of fat $\%$ with fat yield, protein $\%$ and protein yield $(0.49,0.97$ and 0.44 , respectively).

\section{Heritability estimates}

Heritability estimates of some milk production and reproduction traits were summarized in Table 1. High and similar heritability estimates for each of TMY and 305-DMY $(0.33 \pm 0.02)$ which indicated the possibility of improvement of these traits by genetic selection. These estimates were particularly similar to those obtained by Elshalmani [17] and Mostafa [24]. However, the estimates were higher than those reported by Ayied et al. [25] and Hammoud et al. [26], which could be explained by different number of animals and/or different estimation methods. Heritability estimates of fat and protein \% were 0.38 and 0.25 , respectively. These estimates were higher than those reported previously [27,28]. High heritability estimates for fat and protein yields $(0.37$ and 0.32 , respectively), which are consistent with those obtained by Mashhadi et al. [29], but are higher than those recorded by others $[30,31]$. Days in milk had a medium heritability estimate (0.11), which was similar to those reported previously [32,33]. On the other hand, these estimates were much higher than those reported by Ayied et al. [25], but were lower than those recorded by others $[5,34]$.
Medium estimates were recorded for DP (0.24) that were similar to the estimates reported by Goshu et al. [5] whereas, were higher than those registered by Salem et al. [1] and Ibrahim [35], but lower than those published previously $[25,36]$.

The heritability estimate of CI was very low (0.03). Similar estimates were reported previously [27,33]. However, higher estimates were published by Islam et al. [37]. Very low estimate was recorded for DO (0.06). Concurrent estimates were published by others $[27,38]$. On the contrary, a high heritability estimate for DO (0.51) in Friesian cows under Sudanian tropical conditions was reported by Abdel-Gader et al. [33]. High heritability estimate was detected for S/C (0.43). Controversy results were reported previously [27,39]. However, this estimate was in the same line of that obtained by Osman et al. [40]. Age at first calving had a high heritability estimate (0.40), which was consistent with that reported by Ayied et al. [25] and Ghiasi et al. [38]. In contrast, low heritability estimates were mentioned previously [41,42]. The low heritability of fertility traits (DO and $\mathrm{CI}$ ) indicated that the influence of herd management and other environmental factors were greater than genetic background. Also, the possibility of improvement through direct selection was difficult. Whereas, medium heritability estimates for DP and protein percent indicated possibility of improvement through both genetic selection and by good managerial and environment conditions. However, high heritability estimate for TMY, 305-DMY, fat percent, fat yield, protein yield, AFC and S/C indicated the possibility of improvement of through direct selection.

\section{Breeding values}

Minimum, maximum, range and standard errors of cow, sire and dam breeding values for some milk production and reproduction traits were presented in Table 2. The breeding values for TMY, 305-DMY and DP of cows ranged between -4463 and $4969,-3854$ and $3086 \mathrm{~kg}$ and between -22.22 and 123.91days, respectively while the corresponding values for dams were between -2535 and 3034, -2598 and $1709 \mathrm{~kg}$, and between -15.92 and 57.13 days, respectively. Moreover, the 
corresponding values for sires between -4754 and $3972,-3736$ and $2151 \mathrm{~kg}$ and between 24.08 and 110.01 days, respectively. The range of breeding values for 305-DMY were higher than those reported by Atil and Khattab [43]. The range of predicted sire breeding values for single trait analyses ranged from -391 to 700 $\mathrm{kg}$ for 305-DMY [44]. Also, the range was between -656 and 455 for sire, between -186 and $386 \mathrm{~kg}$ for cows was reported by Katok and Yanar [45]. The range of breeding values for TMY and 305-DMY for cows was between
-8857 and 10253, and between -5662.1 and $2817 \mathrm{~kg}$, respectively and between -372.2 and 399.7 for sire and between -455.9 and 337.7 $\mathrm{kg}$, respectively for cows. While, dam breeding values for these traits ranged between -344.7 and 724.5 and between -895.8 and $604.2 \mathrm{~kg}$, respectively [26]. Higher range for TMY (-442 and $1265 \mathrm{~kg}$ ) were depicted by Rehman and Khan [46]. The range for TMY $(6006 \mathrm{~kg}$ and $10280 \mathrm{~kg}$ ) for single-trait and multi-trait analyses respectively was stated in previous studies [47].

Table2: Range of predicted breeding values of Holstein-Friesian cows, sires and dams for some productive and reproductive traits when using records of all lactations

\begin{tabular}{|c|c|c|c|}
\hline Traits & Minimum \pm SE & Maximum \pm SE & Range \\
\hline \multicolumn{4}{|c|}{ Cows breeding value } \\
\hline TMY (kg) & $-4463 \pm 0.80$ & $4969 \pm 1.48$ & 9432 \\
\hline 305-DMY (kg) & $-3854 \pm 0.60$ & $3086 \pm 1.06$ & 6940 \\
\hline Fat $\%$ & $-0.98 \pm 0.14$ & $1.23 \pm 0.26$ & 2.21 \\
\hline Fat yield (kg) & $-138.5 \pm 2.58$ & $205.76 \pm 4.69$ & 344.26 \\
\hline Protein $\%$ & $-0.57 \pm 0.11$ & $0.73 \pm 0.18$ & 1.3 \\
\hline Protein yield (kg) & $-105.32 \pm 2.16$ & $137.2 \pm 3.75$ & 242.52 \\
\hline DIM (day) & $-70.82 \pm 2.60$ & $86.27 \pm 3.46$ & 157.09 \\
\hline $\mathrm{DP}$ (day) & $-22.22 \pm 1.22$ & $123.91 \pm 1.95$ & 146.13 \\
\hline AFC (month) & $-7.90 \pm 2.80$ & $10.17 \pm 3.39$ & 18.07 \\
\hline $\mathrm{CI}($ day $)$ & $-14.43 \pm 1.20$ & $15.58 \pm 1.35$ & 30.01 \\
\hline $\mathrm{DO}($ day $)$ & $-27.27 \pm 1.69$ & $37.49 \pm 2.05$ & 64.76 \\
\hline \multicolumn{4}{|c|}{ Sires breeding value } \\
\hline TMY (kg) & $-4754 \pm 0.61$ & $3972 \pm 1.75$ & 8726 \\
\hline 305-DMY (kg) & $-3736 \pm 0.44$ & $2151 \pm 1.25$ & 5887 \\
\hline Fat $\%$ & $-0.57 \pm 0.11$ & $1.574 \pm 0.32$ & 2.14 \\
\hline Fat yield (kg) & $-121.17 \pm 1.92$ & $175.65 \pm 5.66$ & 296.82 \\
\hline Protein $\%$ & $-0.38 \pm 0.08$ & $0.93 \pm 0.21$ & 1.31 \\
\hline Protein yield (kg) & $-84.86 \pm 1.54$ & $113.53 \pm 4.39$ & 198.39 \\
\hline DIM (day) & $-69.31 \pm 1.73$ & $62.98 \pm 3.67$ & 132.29 \\
\hline DP (day) & $-24.08 \pm 0.91$ & $110.01 \pm 2.17$ & 134.09 \\
\hline AFC (month) & $-8.46 \pm 1.58$ & $7.36 \pm 3.82$ & 15.82 \\
\hline CI (day) & $-16.55 \pm 1.02$ & $12.65 \pm 1.37$ & 29.20 \\
\hline DO (day) & $-28.51 \pm 1.22$ & $29.80 \pm 2.12$ & 58.31 \\
\hline \multicolumn{4}{|c|}{ Dams breeding value } \\
\hline TMY (kg) & $-2535 \pm 1.23$ & $3034 \pm 1.81$ & 5569 \\
\hline 305-DMY (kg) & $-2598 \pm 0.88$ & $1709 \pm 1.30$ & 4307 \\
\hline Fat $\%$ & $-0.56 \pm 0.22$ & $0.97 \pm 0.33$ & 1.53 \\
\hline Fat yield (kg) & $-84.90 \pm 3.91$ & $95.17 \pm 5.86$ & 180.07 \\
\hline Protein $\%$ & $-0.25 \pm 0.15$ & $0.50 \pm 0.21$ & 0.75 \\
\hline Protein yield (kg) & $-61.83 \pm 3.11$ & $73.14 \pm 4.55$ & 134.97 \\
\hline DIM (day) & $-37.97 \pm 3.04$ & $65.02 \pm 3.75$ & 102.99 \\
\hline DP (day) & $-15.92 \pm 1.68$ & $57.13 \pm 2.21$ & 73.97 \\
\hline AFC (month) & $-5.75 \pm 2.99$ & $5.09 \pm 3.89$ & 10.84 \\
\hline CI (day) & $-5.92 \pm 1.30$ & $10.56 \pm 1.37$ & 16.48 \\
\hline DO (day) & $-16.05 \pm 1.89$ & $21.11 \pm 2.215$ & 37.16 \\
\hline
\end{tabular}

TMY, total milk yield; 305-DMY, 305-days milk yield; DIM, days in milk; DP, dry period; AFC, Age at first calving; CI, calving interval; DO, days open;"Range is calculated as maximum minus minimum of the breeding value. 
For DP, the range was higher than those reported by El-Arian et al. [48] and Hatem and Ismail [49]. Sire breeding value for DP was ranged between -15.95 to 49.60 days [25]. The range was between -78 and 116 was recorded by Rehman and Khan [46]. Also, the range of sire breeding value for DP (34.62 day), for dams (29.35 day) and (53.71day) for cows was reported by Mariz [3]. The values for fat $\%$, fat yield, protein $\%$ and protein yield of cows ranged between -0.98 and $1.23 \%,-138.5$ and $205.76 \mathrm{~kg},-0.57$ and $0.73 \%$, and between 105.32 and $137.2 \mathrm{~kg}$, respectively while, the corresponding values for dams were between 0.56 and $0.97 \%,-84.9$ and $95.17 \mathrm{~kg},-0.25$ and $0.50 \%$, and between -61.83 and $73.14 \mathrm{~kg}$, respectively. Moreover, the corresponding values for sires were between -0.57 and $1.574 \%,-121.17$ and $175.65 \mathrm{~kg},-0.38$ and $0.93 \%$, and between -84.86 and $113.53 \mathrm{~kg}$, respectively. The average of sire breeding values for fat and protein yields were 26.6 $\mathrm{kg} / \mathrm{lactation}$ and $15.7 \mathrm{~kg} / \mathrm{lactation}$, respectively [50]. The mean of breeding values of sires were $3.7,2.3,-0.036$ and -0.028 for fat and protein yields, percent of fat and protein, respectively [29]. The range of predicted sire breeding values for single trait analyses ranged from -14.74 to $22.06 \mathrm{~kg}$ for 305 day fat yield and from -11.09 to $21.80 \mathrm{~kg}$ for 305 day protein yield [44]. The estimated sire breeding value for fat yield varied from 17.65 to -21.6 $\mathrm{kg}$ and cow breeding value for the same trait varied from 16.57 to $-7.35 \mathrm{~kg}$ [45].

Cow, sire and dam breeding values for DIM in the present study were ranged between (70.82 and 86.27 days), (-69.31 and 62.98 days) and (-37.97 and 62.02 days), respectively. The range of DIM obtained in the present study was higher than those published in previous studies $[43,49]$. The range between -5.44 and 6.30 days for sire was reported previously [25]. The range between (-303.4 and 350.8 days), (-7.1 and 5.7 days) and (-2.4 and 3.2 days) for cow, sire and dam, respectively was mentioned by Hammoud and Salem [26]. The breeding values for $\mathrm{CI}$ and $\mathrm{DO}$ of cows ranged between -14.43 and 15.58 and between -27.27 and 37.49 days, respectively while, the corresponding values for dams were between -
5.92 and 10.56 and between -16.05 and 21.11 days, respectively. Moreover, for sires they were between -16.55 and 12.65 and between 28.51 and 29.80 days, respectively. The cow, sire and dam breeding values for CI ranged between (-1.00 and1.03), (-1.23and 0.95) and $(-0.54$ and 0.59$)$, respectively [3]. The range from -8.14 to 11.91 days for sires was stated by Ayied et al. [25]. Cows breeding value for DO ranged from -278.8 and 495 days [26]. While, for dams varied from -10.2 and 16.5 days and for sires -16.4 and 29.7. The values for cow, sire and dam ranged between $(-50.13$ and144.30), (37.59 and 170.46) and (-24.42 and 66.31), respectively [3].

Cow, sire and dam breeding values for AFC in the current study were ranged between (7.90 and 10.17 months), (-8.46 and 7.36 months) and (-5.75 and 5.09 months), respectively and these were higher than those reported previously $[49,51]$. The range from 2.10 to 2.28 months, for sires was recorded by Ayied et al. [25]. The range from -3.47 to 2.68 months was estimated by Moawed [52]. The range of the cow breeding values for a trait in a given herd indicated the amount of genetic variation among cows. The wider the range is the wider the genetic variation and this gives the opportunity for improving the considered trait through selection according to the superiority of the cow breeding value.

\section{Genetic trends}

Genetic trends of some milk production and reproduction traits were presented in Figure 1 and Figure 2 (A). Figure 1 (A) showed that the genetic trend of 305-DMY was positive throughout the period from 2002-2006, then declined till 2008 and rose again till 2010 and estimated to be $2.68 \mathrm{~kg} /$ year. The positive values of regression coefficient suggest genetic improvement in the farm for 305DMY and right selection procedures. On the other hand, a declined trend in 305-DMY was observed throughout the period from 19982002. The present results are in disagreement with those reported by Hammoud and Salem [26] and Effa et al. [53], but in accordance with findings of others $[45,54,55]$. 


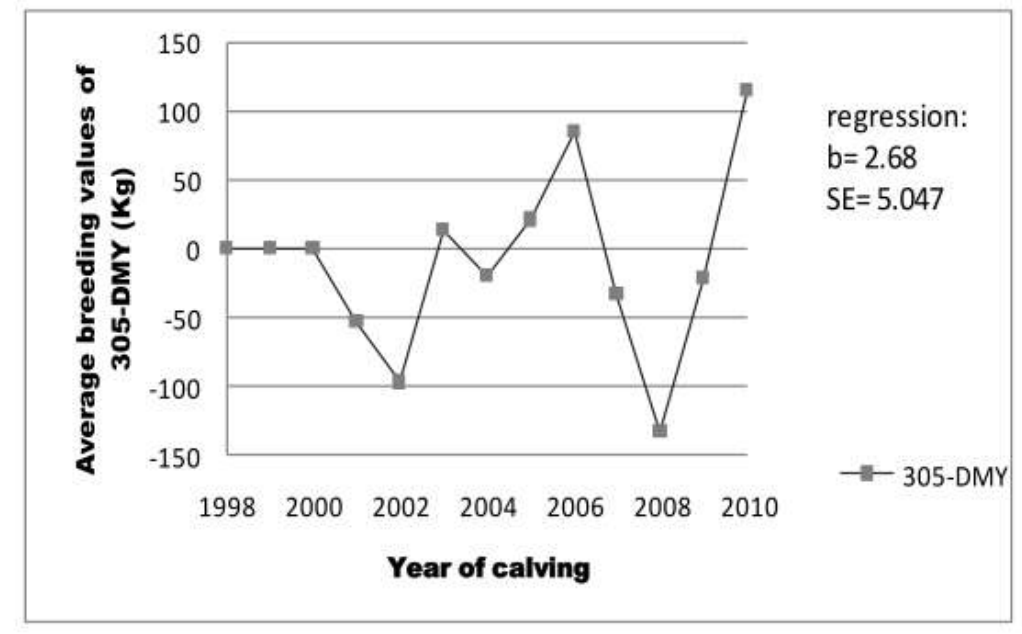

(A)

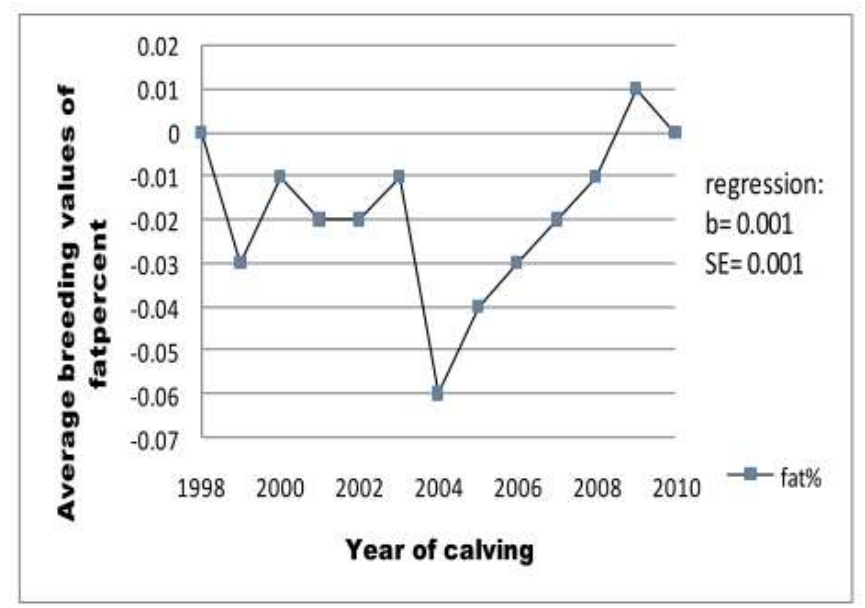

(C)

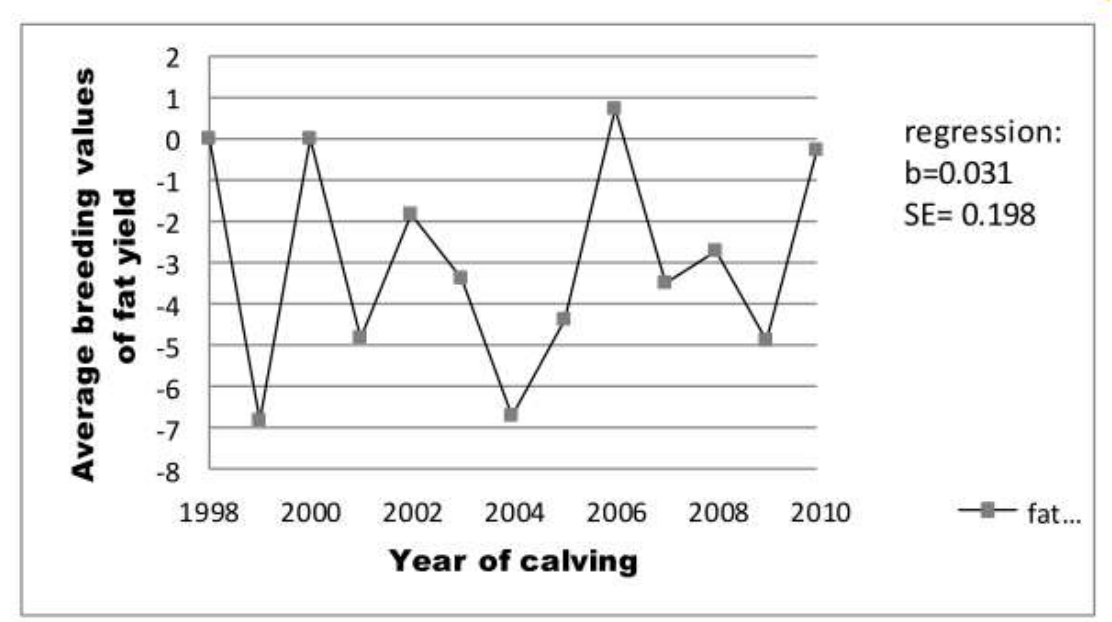

(B)

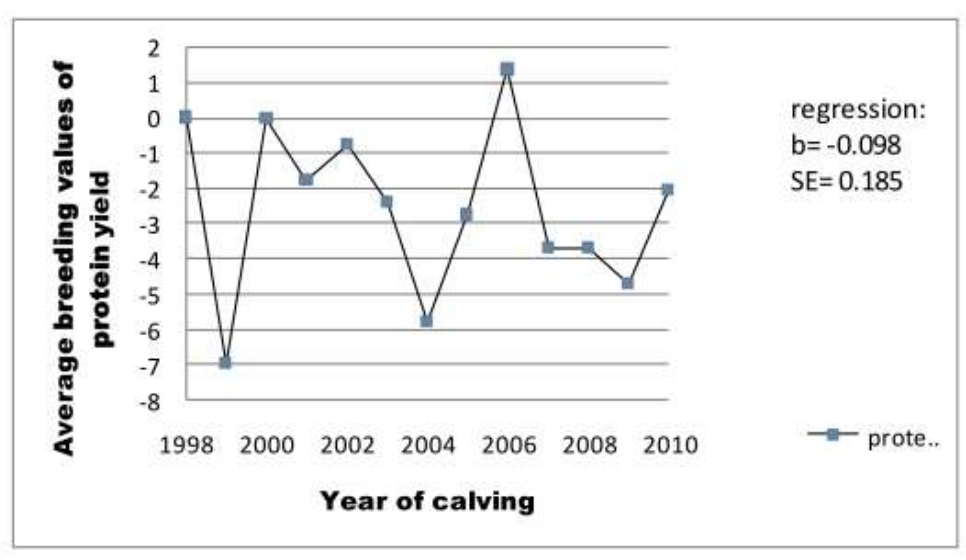

(D)

Figure 1: Genetic trend for some productive traits in Holstein-Friesian cows in Egypt

(A): genetic trend for 305-day milk yield

(B): genetic trend for fat yield

(C): genetic trend for fat $\%$

(D): genetic trend for protein yield 


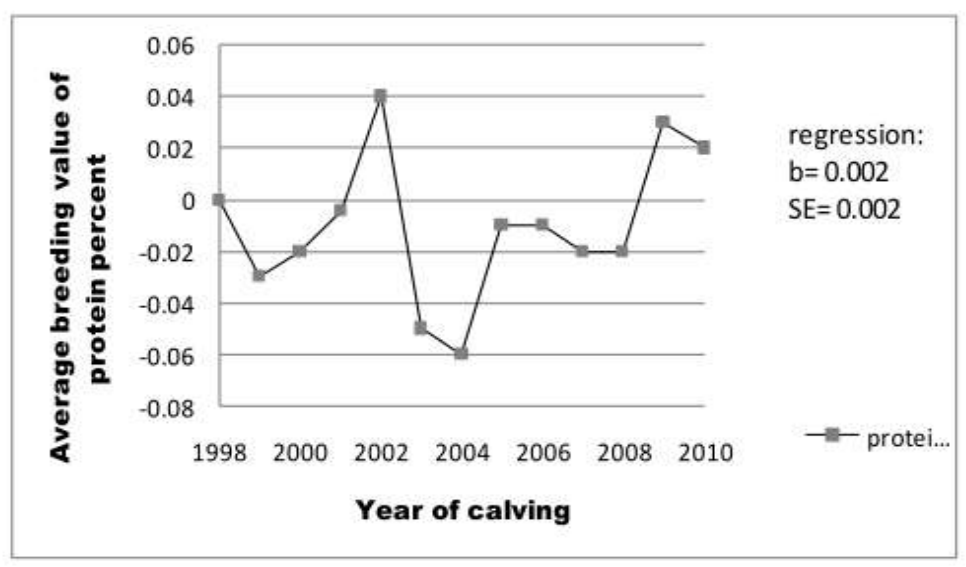

(A)

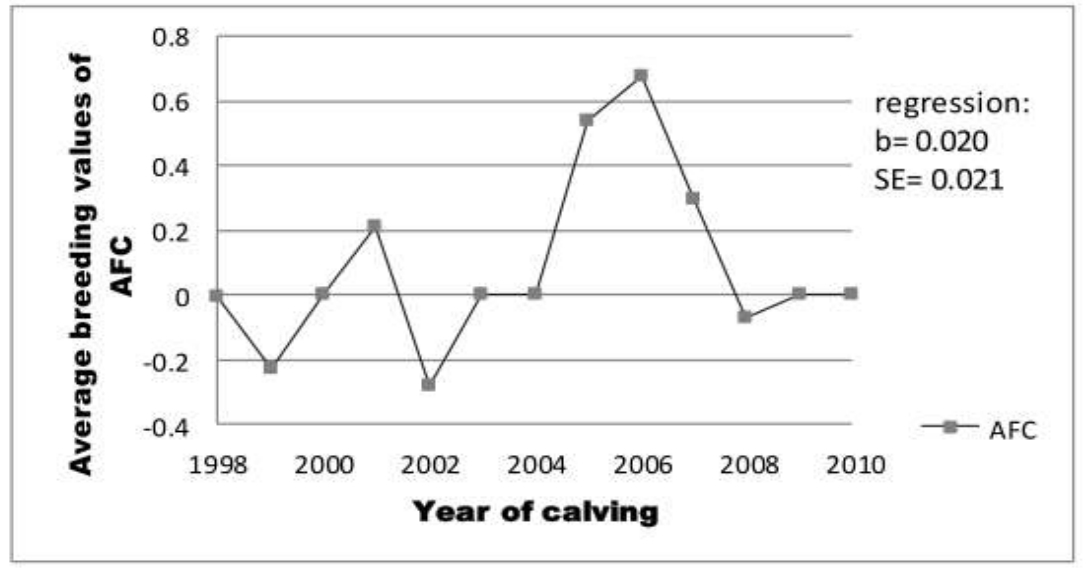

(B)

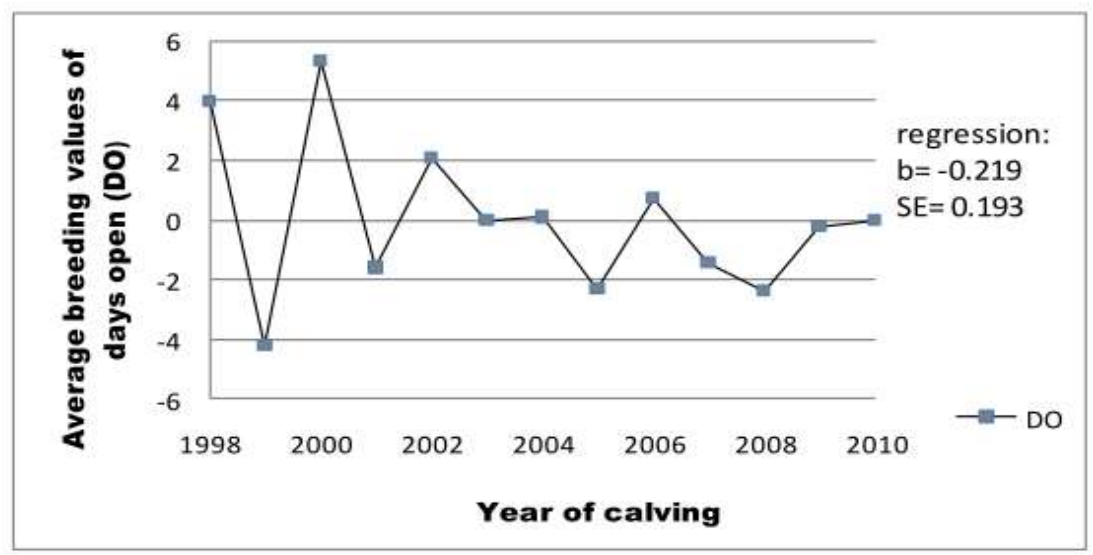

(C)

Figure 2: Genetic trend for protein percent and some reproductive traits of Holstein-Friesian cows in Egypt (A): Genetic trend for protein percent (B): Genetic trend for age at first calving

(C): Genetic trend for days open 
Figures 1 (B-D) and Figure 2 (A) showed the genetic trends of fat yield, fat $\%$, protein yield and protein $\%$, respectively. All of the annual genetic trends were positive and estimated as $0.031 \mathrm{~kg} /$ year, $0.001 \% /$ year and $0.002 \% / y e a r$ for (fat yield, fat $\%$ and protein $\%$, respectively). In contrast, they were negative for protein yield $(-0.098)$. The current results were in agreement with those recorded by others $[6,45,56]$, but controversy with Khanzadeh et al. [28], Abdullahpour et al. [57] and Hossein-Zadeh [58]. The high positive genetic trends for fat and protein yields ensured the strong relationship between milk yield and these traits genetically as compared to percentage traits. Figure 2 (B) showed a positive genetic trend for AFC $(0.020$ month/year), which was in agreement with those reported by others [53,59], but in disagreement with those previously reported $[58,60]$. Figure 2 (C) showed a negative genetic trend for days open. Regression coefficient for this trait was -0.219 days/year, which was parallel with those reported by Elshalmani [17] and Solemani-Baghshan et al. [59] and inconsistent with Hammoud and Salem [26]. Positive genetic trends for 305DMY, AFC, fat $\%$, fat yield and protein $\%$ indicated that there was a genetic improvement in these traits in the desirable direction over the year, but negative genetic trends for DO and protein yield indicated a decrease in mean breeding value over the study period.

\section{Conclusion}

The genetic correlations between the studied traits showed great variability from very high positive to very low negative values. Strong heritability estimates were recorded for all studied traits with the exception of days in milk, calving interval and days open which revealed low estimates. Higher range of the cow breeding values than either sires or dams revealed a wider genetic variation and a good chance of selecting the superior cows. Positive genetic trends for 305-day milk yield, age at first calving, fat $\%$, fat yield and protein $\%$ indicated that there was a genetic improvement in these traits in desirable direction over the year, but negative genetic trends for days open and protein yield indicated a decrease in mean of breeding values for these traits over the period of the current study.

\section{Conflict of interest}

The authors have no any conflict of interest.

\section{References}

[1] Salem, M.A.; Esmail, H.M.; Sadek, R.R. and Nigm, A.A. (2006): Phenotypic and genetic parameters of milk production and reproductive performance of Holstein cattle under the intensive production system in Egypt. Egyptian J Anim Prod, 43(1): 1-10.

[2] Hammoud, M.H.; El-Zarkouny, S.Z. and Oudah, E.Z.M. (2010): Effect of sire, age at first calving, season of calving and parity on reproductive performance of Friesian cows under semiarid condition in Egypt. Arch Zootech, 13(1): 60-82.

[3] Mariz, O.M.M. (2014): Genetic and environmental factors affecting calving interval in dairy farms. M.Sc. Thesis, Fac. of Vet., Med., Zagazig. Univ., Egypt.

[4] Sarakul, M.; Koonawootritriron, S.; Elzo, M.A. and Suwanasopee, T. (2011): Factors associated with dairy cattle genetic improvement for milk production at farm level in Central Thailand. J Anim Sci, 24: 1031-1040.

[5] Goshu, G.; Singh, H.; Petersson, K.J. and Lundeheim, N. (2014): Heritability and correlation among first lactation traits in Holstein Friesian cows at Holeta Bull Dam Station, Ethiopia. International Journal of Livestock Production, 5(3): 47-53.

[6] Yaeghoobi, R.; Doosti, A.; Noorian, A.M. and Bahrami, A.M. (2011): Genetic parameters and trends of milk and fat yields in Holstein's Dairy cattle of west provinces of Iran. International Journal of Dairy Science, 6: 142-149.

[7] NRC, (1989): Nutrient requirements of dairy cattle. $6^{\text {th }}$ Edition. National Academy of Science, National Research Council. Washington, D.C. USA.

[8] Boldman, K.G.; Kriese, L.A.; Van Vleck, L.D. and Kachman, S.D. (1995): A manual for use of MTDFRML. Department of Agriculture/Agriculture Research Service, Lincoln, 120 PP.

[9] Ahmed, M.; Van der werf, J.H.J. and Javed, K. (2001): Genetic and phenotypic 
correlations for some economic traits in dairy cattle. Pak Vet J, 21(2): 81-86.

[10] Montaldo, H.H.; Castillo-Juarez, H.; Valencia-Posadas, M.; CienfuegosRivas, E.G. and Ruiz-Lopez, F.J. (2010): Genetic and environmental parameters for milk production, udder health and fertility traits in Mexican Holstein cows. J Dairy Sci, 93: 2168-2175.

[11] Toghiani, S. (2012): Genetic relationships between production traits and reproductive performance in Holstein dairy cows. Archiv Tierzucht, 55(5): 458-468.

[12] Boujenane, I. (2002): Estimation of genetic and phenotypic parameters for milk production in Moroccan HolsteinFriesian cows. Revue Elev Med Vet Pays Trop, 55(1): 63-67.

[13] Hashemi, A. and Nayebpour, M. (2008): Estimation of genetic and phenotypic parameters for milk production in Holstein-Friesian cows. Research Journal of Biological Science, 3(6): 678682.

[14] Yousefi-Golverdi, A.; Hafezian, H.; Chashnidel, Y. and Farhadi, A. (2012): Genetic parameters and trends of production traits in Iranian Holstein population. Afr J Biotechnol, 11(10): 2429-2435.

[15] Radwan, H.A.A.; Abo Elfadl, E.A. and Fardos, A.M. (2015): Estimation of population parameters of some economic traits in Holstein Friesian cows by statistical program. Global Veterinaria, 14(1): 129-135.

[16] Riecka, Z. and Candrak, J. (2011): Analysis of relationship between production and reproduction traits of Holstein cattle population in Slovak Republic. Anim Sci Biotechnol, 44(1): 332-336.

[17] El-shalmani, A.F. (2011): Evaluation of production performance in relation to genetic structure of some economical traits in Friesian cows. PhD. Thesis, Fac. of Agric. Saba Basha. Alex. University, Egypt.
[18] Sahebhonar, M. (2007): Estimation of genetic trend for production traits and determining the impact of some factors on it in Iranian Holstein cattle. (In Persian), M. Sc. Thesis, University of Tehran, Iran.

[19] Veerkamp, R.F.; Koenen, E.P.C. and De Jong, G. (2001): Genetic correlations among body condition score, yield and fertility in first-parity cows estimated by random regression models. J Dairy Sci, 84: 2327-2335.

[20] Mohiuddin, G.; Ahmad, M.; Khan, Z.; Akhtar, P. and Ali, S. (1991): Genetic, phenotypic and environmental correlations between milk yield and some other economic traits in Sahiwal cattle. Pak Vet J, 11: 113-116.

[21] Van-Raden, P.M.; Sanders, A.H.; Tooker, M.E.; Miller, R.H.; Norman, H.D.; Kuhn, M.T. and Wiggans, G.R. (2004): Development of a national genetic evaluation for cow fertility. J Dairy Sci, 87(7): 2285-2292.

[22] Makgahlela, M.L.; Banga, C.B.; Norris, D.; Dzama, K. and Ngami, J.W. (2007): Genetic correlations between female fertility and production traits in South African Holstein cattle. S Afr J Anim Sci, 37(3): 180-188.

[23] Dechow, C.D.; Rogers, G.W.; Cooper, J.B.; Phelps, M.I. and Mosholder, A.L. (2007): Milk, fat, protein, Somatic cell score and days open among Holstein, Brown Swiss and their crosses. J Dairy Sci, 90: 3542-3549.

[24] Mostafa, M.A. (2009): Genetic parameters and breeding values for productive, reproductive and persistency of milk yield traits of culled cows and their contemporaries retained in herds of Friesian cattle at different lactations. Mansoura Univ. J Agric Sci, 34(9): 9389-9404.

[25] Ayied, A.Y.; Jadoa, A.J. and Abdulrada, A.J. (2011): Heritabilities and breeding values of production and reproduction traits of Holstein cattle in Iraq. Journal of Basrah Researches (Sciences), 37(4 A): 66-70. 
[26] Hammoud, M.H. and Salem, M.M.I. (2013): The genetic evaluation of some first lactation traits of Holstein cows in Egypt. Alex J Agric Res, 58(1): 1-8.

[27] Solarte, C.E.; Gema, P. and Zambrano, L. (2012): Characterization and genetic evaluation of Holstein cattle in Narino, Colombia. Rev Colomb Cienc Peeu, 25: 539-547.

[28] Khanzadeh, H.; Hossein-Zadeh, N.G. and Naserani, M. (2013): Estimation of genetic parameters and trends for milk, fat and protein percentages in Iranian Holstein using random regression test day model. Archiv Tierzucht, 56(47): 487-496.

[29] Mashhadi, M.H.; Kashan, N.E.J.; Nassiry, M.R. and Torhizi, R.V. (2008): Prediction of breeding value and genetic parameter in Iranian Holstein bulls for milk production traits. Pak J Biol Sci, 11(1): 108-112.

[30] Razmkabir, M. (2011): Genetic evaluation of production traits with random regression model in Holstein dairy cattle. Department of Animal Science, Ph.D. Thesis Univ Tehran, Iran (in Persian).

[31] Bohlouli, M. and Alijani, S. (2012): Estimation of genetic parameters of milk production traits of Iranian Holstein dairy cattle using multi-trait random regression model. Livestock Research for Rural Development, 24, Article \#207. Retrieved September 29, 2017, from

http://www.lrrd.org//rrd24/11/bohl24207 .htm.

[32] Atil, H. (2006): A comparison of different selection indices for genetic improvement for milk traits in Holstein Friesian cattle in Turkey by using one standard deviation as relative economic weight. Pak J Biol Sci, 9(2): 285-288.

[33] Abdel-Gader, A.Z.; Khair, M.; Ahmed, A.; Lutfi, M.A. and Peters, K.J. (2007): Milk yield and reproductive performance of Friesian cows under Sudan tropical condition. Archiv Tierzucht, 50(2): 155164.
[34] Nawaz, A.; Nizamanil, A.H.; Marghazani, I.B. and Nasrullah, A.F. (2013): Influence of genetic and environmental factors on lactation performance of Holstein-Friesian cattle in Baluchistan. $\mathbf{J}$ Anim Plant Sci, 23(1): 17-19.

[35] Ibrahim, S.S.S. (2006): Genetic analysis for some productive and reproductive traits in dairy cattle. Ph.D. Thesis, Fac. of Agric., Banha Branch, Zagazig. Univ., Egypt.

[36] Afifi, E.A.; Abdel-Glil, M.F.; Salem, M.A.; Arafa, S.A. and Ibrahim, S.S.S. (2004): Genetic aspects of age at first calving and longevity traits in a commercial Holstein herd raised under Egyptian conditions. Annals of Agricultural Science, Mashtohor, 42(3): 1027-1038.

[37] Islam, S.S.; Ahmed, A.R.; Ashraf, A. and Khanam, N. (2004): Genetic and phenotypic parameters on reproductive traits of crossbred cattle in a selected farm of Bangladesh. Pak J Biol Sci, 7(7): 1269-1273.

[38] Ghiasi, H.; Pakdel, A.; Nejati-Javaremi, A.; Mehrabani-Yeganeh, H.; Honarvar, M.; Gonzalez-Recio, O.; Carabano, M.J. and Alenda, R. (2011): Genetic variance components for female fertility in Iranian Holstein cow. Livest Sci, 45:1245-1249.

[39] M'hamdi, N.; Aloulou, R.; Bouallegue, S.K. and Hamouda, M. (2010): Phenotypic and genetic parameters of reproductive traits in Tunisian Holstein cows. Biotechnology in Animal Husbandry, 36(5-6): 297-307.

[40] Osman, M.M.; El-Bayoumi, K.M. and Moawed, S.A. (2013): Estimation of heritabilities, genetic correlations, phenotypic correlations and genetic correlations and genetic trends for production and reproduction traits of Holstein-Friesian dairy cattle using sire model. Suez Canal Vet Med J. XVIII(1): 115-128.

[41] Chookani, A.; Dadpasandi, M.; Mirzaei, H.R.; Rokouii, M. and Sayadnezhad, M.B. (2010): An estimation of genetic 
parameters for some reproductive traits and their relationships to milk yield in Iranian Holstein cattle. Iranian Journal of Animal Science, 40(4): 53-61.

[42] Usman, T.; Guo, G.; Suhail, S.M.; Qureshi, M.S. and Wang, Y. (2012): Estimation of genetic parameters of reproductive and milk yield traits using multiple-trait animal model in Holstein under subtropical conditions. Journal of Animal and Veterinary Advances, 11(17): 3132-3139.

[43] Atil, H. and Khattab, A. S. (2005): Estimation of genetic trends for productive traits of Holstein Friesian cows in Turkey. Pak J Biol Sci, 8(2): 202-205.

[44] El-Awady, H.G.; Khattab, A.S. and Tozser, J. (2011): Comparison between single and multiple traits animal model for some fertility and milk production traits in Friesian cows in Egypt. AWETH, 7 (4): 111-118.

[45] Katok, N. and Yanar, M. (2012): Milk traits and estimation of genetic, phenotypic and environmental trends for milk and milk fat yields in Holstein Friesian cows. Int J Agric Biol, 14(2): 311-314.

[46] Rehman, Z. and Khan, M.S. (2012): Environmental factors affecting performance traits of Sahiwal cattle in Pakistan. Pak Vet J, 32(2): 229-233.

[47] Shalaby, N.A.; Mostafa, M.A.; AbdelGlil, M.F. and Alemam, M.A.Z. (2009): Genetic evaluation for milk production, reproduction and somatic cell count traits in early lactation for Friesian cattle in Egypt. Journal Agriculture Science, Mansoura University, 34: 9463-9475.

[48] El-Arian, M.N.; El-Awady, H.G. and Khattab, A.S. (2003): Genetic analysis for some productive traits of Holstein Friesian cows in Egypt through MTDFREML program. Egyptian Journal of Animal Production, 40: 99-109.

[49] Hatem, I. and Ismail, A. (2006): Phenotypic and genetic parameters of milk production and reproductive performance of Holstein cattle under the intensive production system in Egypt. (Personal communication).

[50] Sawalha, R.M.; Keown, J.F.; Kachwan, S.D. and Van Vleck, L.D. (2005): Genetic evaluation of dairy cattle with autoregressive covariance structures and with a 305-d model. J Dairy Sci, 88(9): 3346-3353.

[51] Shalaby, N.A. (2005): Genetic evaluation for milk production, reproduction traits and persistency of lactation using single and two-trait animal model analyses for Friesian cows in commercial herds in Egypt. J Agric Sci Mansoura Univ., 30(7): 3637-3653.

[52] Moawed, SH.A.M. (2013): Statistical evaluation of procedures used in estimating population genetic parameters. Ph. D. thesis, Suez Canal University, Egypt.

[53] Effa, K.; Wondatir, Z.; Dessie, T. and Haile, A. (2011): Genetic and environmental trends in the long-term dairy cattle genetic improvement programs in the central tropical highlands of Ethiopia. J Cell Anim Biol, 5(6): 96-104.

[54] Khorshidie, R.; Shadparvar, A.A.; Hossein-Zadeh, N.G. and Shakalgurabi, S.J. (2012): Genetic trends for 305-day milk yield and persistency in Iranian Holsteins. Livest Sci, 144: 211-217.

[55] Nehara, M.; Singh, A.; Gandhi, R.S.; Chakravarty, A.K.; Gupta, A.K.; Sachdeva, G.K. and Singh, R.K. (2012): Phenotypic, genetic and environmental trends of milk production traits in Karan Friesian cattle. Indian J Dairy Sci, 65(3): 42-45.

[56] Radjabalizadeh, K. (2011): Study of genetic trends for production traits in Iranian Holstein cattle. Asian J Anim Vet Adv, 6: 953-957.

[57] Abdullahpour, R.; Shahrbabak, M.M.; Nejati-Javaremi, A.; Torshizi, R.V. and Mrode, R. (2013): Genetic analysis of milk yield, fat and protein content in Holstein dairy cows in Iran: Legendre polynomials random regression in model 
applied. Archiv Tierzucht, 56(48): 497508.

[58] Hossein-Zadeh, N.G. (2011): Genetic and phenotypic trends for age at first calving and milk yield and compositions in Holstein dairy cows. Arch Tierz, 54(4): 338-347.

[59] Solemani-Baghshan, S.; Ansari-Mahyari, S.; Endris, M.A. and Nanaei, H.A. (2014): Estimation of genetic and phenotypic trends for age at first calving, calving interval, days open and number of insemination to conception in Fhan Holstein cows. International Journal of Advanced Biological and Biomedical Research, 2(5): 1307-1314.

[60] Faraji-Arough, H.; Aslaminejad, A.A. and Farhangfar, H. (2011): Estimation of genetic parameters and trends for age at first calving and calving interval in Iranian Holstein cows. Journal of Research in Agricultural Science, 7(1): 79-87.

\section{الملخص العربى}

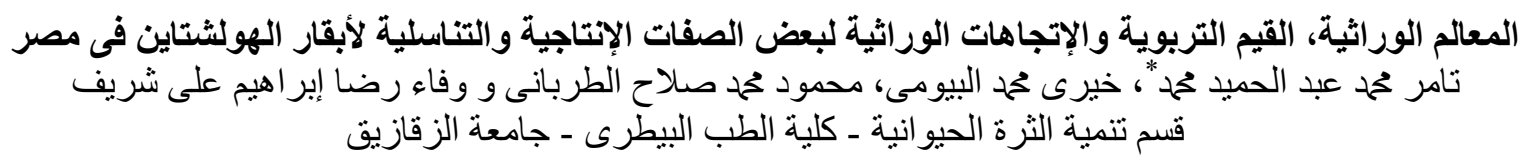

هدفت هذة الدر اسة لقياس المعالم الوراثية والتى تنمل المكافئ الوراثى والإرتباط الجينى وكذلك القيم التربوية و الإتجاهات

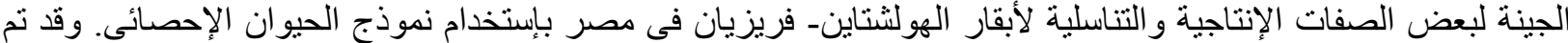

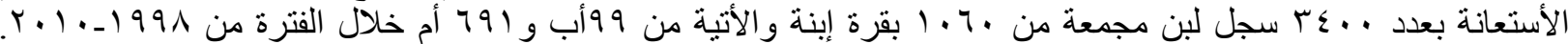

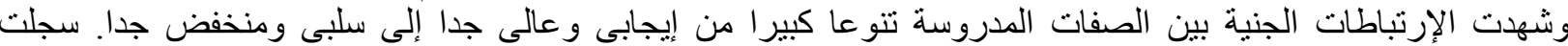

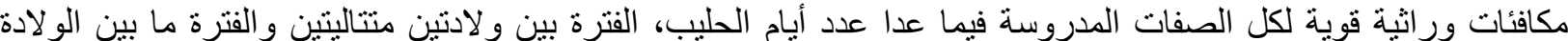

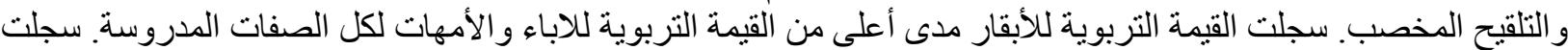

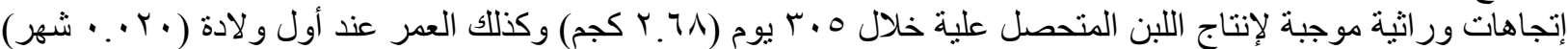

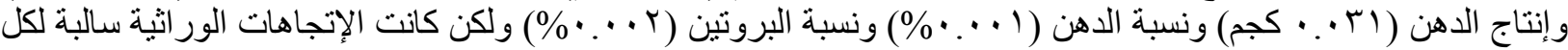

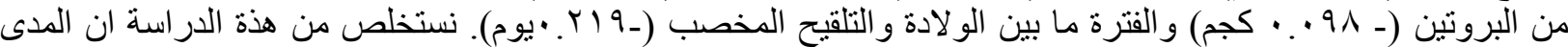

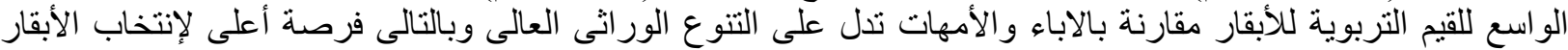

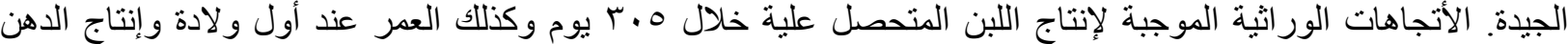
ونسبة الدهن و البروتين تدل على التحسن الوراتى عبر التبر كل السنوات ولكن الإتجاهات الوراتية السالبة لكل من إنتاج البروتين

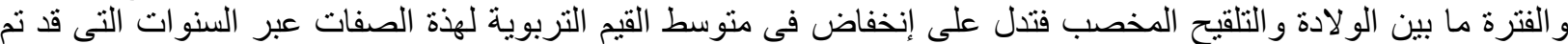
تجميع فيها هذة السجلات. 